\title{
Cell adhesion on Ti surface with controlled roughness
}

\author{
Laura Burgos-Asperilla ${ }^{\mathrm{a}}$, M. Cristina García-Alonso ${ }^{\mathrm{a}, \mathrm{b}, \bowtie}$, M. Lorenza Escudero ${ }^{\mathrm{a}, \mathrm{b}}$, Concepción Alonso ${ }^{\mathrm{a}}$ \\ ${ }^{a}$ Department of Applied Physical Chemistry, Universidad Autónoma de Madrid, \\ Ciudad Universitaria de Cantoblanco, 28049 Madrid, Spain \\ ${ }^{b}$ Department of Surface Engineering, Corrosion and Durability, National Centre for Metallurgical \\ Research (CENIM-CSIC), Avda. Gregorio del Amo 8, 28040 Madrid, Spain \\ Corresponding author: crisga@cenim.csic.es
}

Submitted: 21 January 2015; Accepted: 21 April 2015; Available On-line: 2 J une 2015

\begin{abstract}
In this report, the in situ interaction between Saos-2 osteoblast cells and a smooth Ti surface was examined over time. The adhesion kinetics and mechanisms of cellular proliferation were monitored by quartz crystal microbalance (QCM) and electrochemical impedance spectroscopy (EIS). The rate of Saos-2 attachment on Ti surfaces, obtained from the measurements performed with the QCM, is a first-order reaction, with $\mathrm{k}=2.10^{-3} \mathrm{~min}^{-1}$. The impedance measurements indicate that in the absence of cells, the Ti resistance diminishes over time ( 7 days), due to the presence of amino acids and proteins from the culture medium that have been adsorbed, while in the presence of osteoblasts, this decrease is much greater because of the compounds generated by the cells that accelerate the dissolution of Ti.
\end{abstract}

KEYWORDS: Electrochemical impedance spectroscopy; Quartz crystal microbalance; Saos-2 osteoblasts; Titanium

Citation / Cómo citar este artículo: Burgos-Asperilla, L., García-Alonso, M.C., Escudero, M.L., Alonso, C. (2015) "Cell adhesion on Ti surface with controlled roughness". Rev. Metal. 51(2): e044. doi: http://dx.doi.org/10.3989/ revmetalm.044.

RESUMEN: Adhesión de osteoblastos sobre una superficie de Ti de rugosidad controlada. En este trabajo, se ha estudiado la interacción in situ entre células osteoblásticas Saos-2 y una superficie de Ti de rugosidad controlada a lo largo del tiempo. El estudio de la cinética y los mecanismos de proliferación celular de adhesión se ha realizado a través de la microbalanza de cristal de cuarzo (QCM) y espectroscopía de impedancia electroquímica (EIS). La velocidad de adhesión de los osteoblastos sobre la superficie de Ti obtenida a través de medidas con la QCM, sigue una reacción de primer orden, con $\mathrm{k}=2 \times 10^{-3} \mathrm{~min}^{-1}$. Los ensayos de impedancia indican que, en ausencia de las células, la resistencia del Ti disminuye con el tiempo (7 días), debido a la presencia de aminoácidos y proteínas del medio de cultivo que se han adsorbido, mientras que en presencia de células, esta disminución es mucho mayor debido a los productos metabólicos generados por las células que aceleran la disolución del Ti.

PALABRAS CLAVE: Espectroscopia de impedancia electroquímica; Microbalanza de cristal de cuarzo; Osteoblastos Saos-2; Titanio.

Copyright: (C) 2015 CSIC. This is an open-access article distributed under the terms of the Creative Commons Attribution-Non Commercial (by-nc) Spain 3.0 License.

\section{INTRODUCTION}

Titanium (Ti) and its alloys have been used in dental and orthopedic implants due to their mechanical properties, excellent corrosion behavior, and biocompatibility (Chen et al., 2009). The resistance of
Ti-materials to corrosion is due to the spontaneous formation of a highly protective, passive $\mathrm{TiO}_{2}$ film on the surface. The composition of the passive film (Yang et al., 2004) and the electrochemical processes that occur between the Ti-biomaterial and the cell culture medium are critical for the success of the 
implant (Echevarría and Arroyave, 2003; BurgosAsperilla et al., 2010; Burgos-Asperilla et al., 2014).

The interaction between $\mathrm{Ti}$ surfaces and cells can be studied using techniques such as quartz crystal microbalance (QCM) and electrochemical impedance spectroscopy (EIS). Both techniques are powerful tools that can be used to examine the adhesion kinetics and mechanisms of cell proliferation. Specifically, QCM allows us to monitor the attachment and spread of cells on a particular surface quantitatively in real-time, with no need for destructive interventions. Several surface-adherent cell types have been examined (Marx Kenneth et al., 2003), and various parameters are measured to evaluate the viscoelastic properties of cells adhered to QCM crystal besides frequency shift, such as dissipation, resistance, inductance and transient decay time constants oscillation (Modin et al., 2006).

Electrochemical interactions have been studied between $\mathrm{Ti}$ and its alloys and various cell types, such as osteoblast-like U-2 OS cells (Huang, 2004), Saos-2 human osteoblasts (García-Alonso et al., 2009), and L929 fibroblasts (Hiromoto et al., 2002), by EIS. Valuable data on the interaction between $\mathrm{Ti}$ and Ti-6Al-4V alloy and osteoblast-like cells have been generated (Huang, 2004; Mustafa et al., 2002).

In this report, we have studied the electrochemical interaction between a smooth and reproducible $\mathrm{Ti}$ surface (QCM crystals coated by Ti) and cell culture medium with and without cells by EIS and QCM.

\section{MATERIALS AND METHODS}

Commercial quartz crystal microbalance Ticrystals, $25 \mathrm{~mm}$ in diameter and $300 \mathrm{~nm}$ in thickness, were used as the test specimen. The Ti-crystal samples were washed in distilled water and ethanol and sterilized under UV light for 15 minutes before the culture experiments.

Human osteosarcoma Saos-2 cells (ECACC, Salisbury, UK) were grown in Dulbecco's modified Eagle's medium (DMEM), supplemented with $10 \%(\mathrm{v} / \mathrm{v})$ heat-inactivated fetal bovine serum (FBS), $500 \mathrm{UI} \mathrm{ml}^{-1}$ penicillin, and $0.1 \mathrm{mg} \mathrm{m}^{-1}$ streptomycin. Cells were seeded on Ti-crystals samples at $1.5 \cdot 10^{4}$ cells $\cdot \mathrm{cm}^{-2}$ for impedance measurements and $5 \cdot 10^{4}$ cells $\cdot \mathrm{cm}^{-2}$ for QCM measurements, maintained in the growth medium for 7 days and 1 day, respectively.

An electrochemical cell with a 3-electrode setup was used (Alonso et al., 2008). The area of the working electrode (Ti-QCM samples) was $0.79 \mathrm{~cm}^{2}$. The experiments were performed at $37 \pm 0.5^{\circ} \mathrm{C}$.

The EIS experiments were performed at the corrosion potential by applying a sinusoidal wave of $5 \mathrm{mV}$ at $10^{5} \mathrm{~Hz}$ to $10^{-3} \mathrm{~Hz}$ spaced logarithmically (5 per decade).

The QCM probe was stabilized in air, obtaining a frequency value that was close to $5 \mathrm{MHz}$, after which DMEM at $37 \pm 0.5^{\circ} \mathrm{C}$ was added. Finally, the cells were added over the DMEM electrolyte and the frequency was registered for 24 hours. Trypsin was added to the DMEM culture medium at the end of test in order to detach the adhered cells and to analyze if the frequency is recovered to the initial values.

For the atomic force microscope (AFM) studies, the images were acquired using silicon nitride cantilevers with a nominal probe curvature radius of $10 \mathrm{~nm}$ and a force constant of $40 \mathrm{~N} \mathrm{~m}^{-1}$. For morphological imaging of the Ti-QCM samples, tapping-mode AFM microscopy was used.

For SEM analysis, the Saos- 2 cells cultured on the Ti-QCM surface, were fixed in $2.5 \%$ glutaraldehyde in PBS for 24 hours at $4{ }^{\circ} \mathrm{C}$ and dehydrated at $4{ }^{\circ} \mathrm{C}$ in a series of graded ethanol. Finally, the cells were dried in increasing percentages of tetramethylsylane (TMS) in ethanol. After the dehydration, the Ti-cell surfaces were analyzed on a JEOL-6500F microscope.

\section{RESULTS AND DISCUSSION}

Figure 1 shows a detailed image by AFM $(10 \mu \mathrm{m} \times 10 \mu \mathrm{m})$ of a Ti-QCM substrate with surface roughness RMS (Root Mean Square) of approximately $37 \mathrm{~nm}$-i.e., the Ti-QCM surfaces were smooth on a nanometer scale. Variations in roughness at the nanoscale level can influence the physical, chemical and biological responses of the implant material in environmental medium. Recent studies have shown that surface nanoroughness is important for the osseointegration response. Webster et al. (2000) and Mendonca et al. (2009) demonstrated that nanostructures govern the attachment of proteins to a surface, increasing the adherent cell response in cell cultures that are grown on nanostructure surfaces. Goreham et al. (2013) found that different cell types adhered in lower numbers when the nanotopography feature size increased to $68 \mathrm{~nm}$. On the other hand, results reported by Khung et al. (2008) revealed that cells are even sensitive to nanoscale surface topography with feature sizes of $<20 \mathrm{~nm}$.

Two important properties of the biocompatibility of a material are cell adhesion and proliferation. The adhesion of cells in suspension to a substrate entails the following steps: 1) adsorption of proteins onto the surface; 2) contact of rounded cells with the surface (Fig. 2a); 3) attachment of the cells to the surface; and 4) the spread of cells on the surface (Malik et al., 1992). Figure 2b shows the evolution of the $\Delta f$ values with time when the Saos- 2 cells were added to DMEM, after 2 hours incubation time with DMEM in the absence of cells. The incubation prior to the addition of cells was performed to establish baseline frequency values, corresponding to $\Delta f$ values that were equal to $0 . \Delta f$ is the frequency change between the initial value (decrease of 

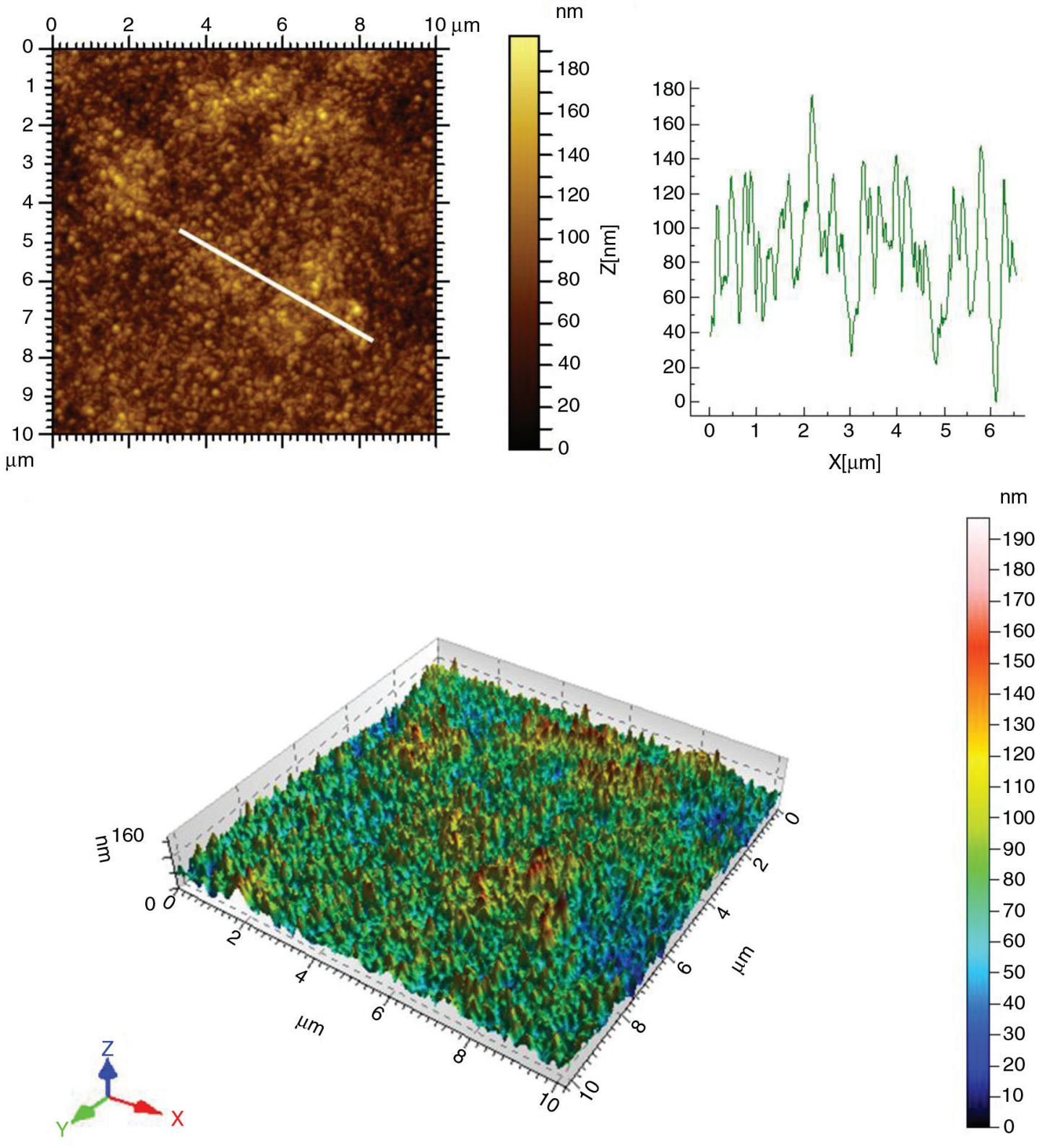

FIgURE 1. Tapping mode AFM image of Ti-QCM surface with height profile.

$863 \mathrm{~Hz}$ when DMEM is added to Ti crystal) and the final frequency (during 24 hours after having added osteoblasts to the DMEM, obtaining a final value of $-421 \mathrm{~Hz}$ with respect to the initial frequency value with DMEM). Following the addition of cells, there was an initial step of decreasing in frequency as the cells settle toward, made contact with, and adhered to the titanium surface. These changes in frequency peaked 24 hours after the addition of Saos- 2 cells. The $\Delta f$ for DMEM was $868 \mathrm{~Hz}$, which is higher than that of water $(700 \mathrm{~Hz})$ due to the presence of salts and proteins adsorbed to the Ti surface.

When the cells were injected into the Ti surface in growth medium, the $\Delta f$ was $421 \mathrm{~Hz}$ after the
24 hours that was required to complete the attachment. Because DMEM and DMEM with Saos-2 cells had similar viscosities, frequency shifts were assigned to the response of cells that attached to the crystal. Owing to the cells behave viscoelastically, the Sauerbrey equation does not apply, but for comparative purposes, osteoblasts can be considered to behave like a viscous medium. The decrease in the frequency versus time can be used to study the adsorption kinetics. This process of decrease in frequency can be controlled by the transport (diffusion) or by the adsorption kinetics, which predicts dependencies with the time $\mathrm{t}^{1 / 2}$ or exponential, respectively. 
(a)

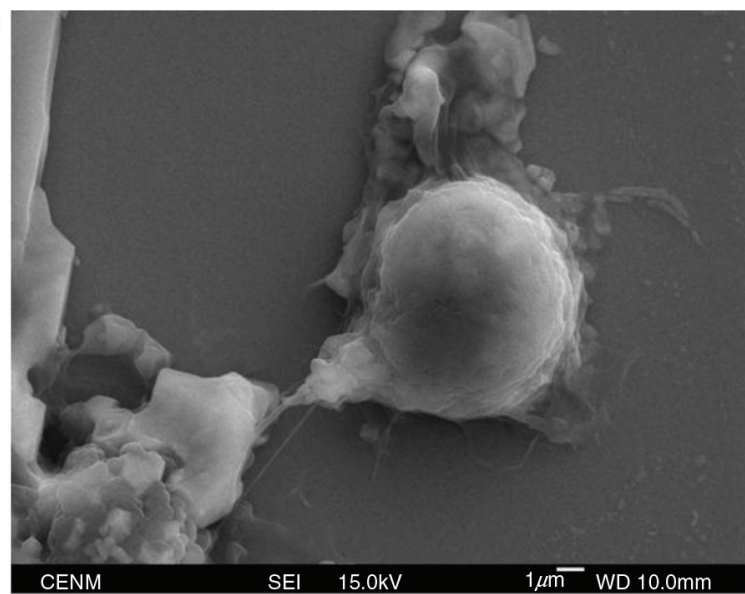

(b)

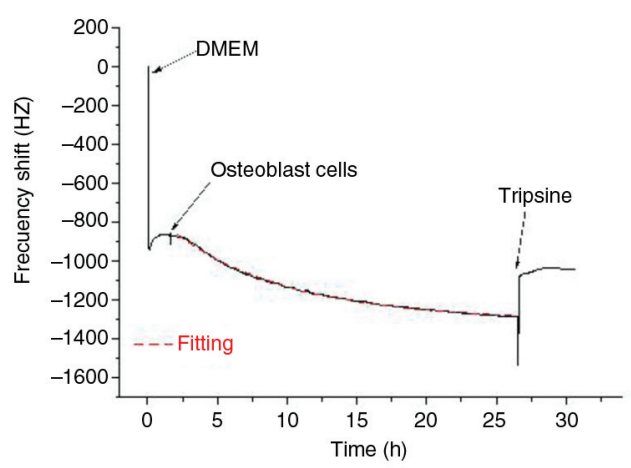

FIGURE 2. a) SEM image of cellular adhesion for Saos-2 osteoblast. b) Change in resonant frequency of crystal upon addition of DMEM, Saos-2 osteoblast suspended in growth medium and finally, trypsin for detaching the cells. The dashed line is the kinetic fitting to experimental data.

The dashed line in Fig. $2 b$ is a kinetic fitting to the experimental data, which assumes that the rate of Saos-2 attachment is a first-order reaction (Eq. 1):

$\Delta \mathrm{f}=\Delta \mathrm{f}_{\mathrm{m}}\left(1-\mathrm{e}^{-\mathrm{kt}}\right)$

where $\Delta f$ is the change in frequency at a time $t, \Delta f_{m}$ $(421 \mathrm{~Hz})$ is the change in frequency between the initial and the final state and $k$ is the first-order kinetics constant expressed in $\min ^{-1}\left(\mathrm{k}=2 \cdot 10^{-3} \mathrm{~min}^{-1}\right)$. This behavior indicates that the process is not controlled by diffusion but the adsorption rate of osteoblasts on the Ti surface. Redepenning et al. (1993) observed similar behavior for a single layer of osteoblasts using the Kanazawa equation (Kanazawa and Gordon, 1985). If these results are compared with the adhesion kinetics for other cellular lines one concludes that, in this case, the kinetics is very slow, since during the testing time there was no observed increase in the frequency due to stiffening of the attached cells (Galli Marxer et al., 2003).
When trypsine is added to the culture medium, cells are detached from the surface but frequency is not completely recovered to the initial value. Instead of that, frequency change $(\Delta f)$ decreases to $1046 \mathrm{~Hz}$, i.e., $178 \mathrm{~Hz}$ lower than DMEM values. This decrease is due to the formation of extracellular matrix by cells on Ti crystals that remain adhered on Ti surface.

The adhesion and proliferation processes of osteoblasts on the Ti surface modify not only the composition of the DMEM culture medium but also the electrochemical properties of the metallic surface. The surface properties of the Ti-QCM surfaces are altered as a result of their electrochemical interaction with the cell culture medium and osteoblast cells. Figures $3 \mathrm{a}$ and $\mathrm{b}$ show the daily evolution of the impedance modulus and shift phase angle-versus-frequency (Bode diagrams) of the $\mathrm{Ti}$ surfaces in culture medium (DMEM/Ti-QCM) over 7 days. The impedance measurements showed a similar electrochemical response, independently on immersion time. These impedance diagrams were simulated, considering the equivalent circuit of the inset in Fig. 3e, where Re is the resistance of the electrolyte, and CPE and R2 are attributed to the Ti/DMEM interface, i.e., the constant phase element and resistance of the DMEM/Ti surface interphase, respectively. Table 1 shows the experimental and fitting results for the EIS experiments for each immersion day in DMEM over 7 days.

In the absence of Saos-2, CPE2 values increase slightly with time, probably due to the protein layer becomes more compact. Consequently, R 2 decreases from the third day of testing. These results indicate that in the first steps of immersion rapid adsorption of proteins on the Ti surface occurs; but at longer immersion times, the presence of amino acids and proteins seems to increase the corrosion rate of metallic biomaterials as the decrease of $\mathrm{R} 2$ values over time show. These results agree with those published by Alberts et al. (1990) and Messer et al. (2001). Furthermore, the Ti can be selectively dissolved by the formation of complexes with proteins (Bruneel and Helsen, 1988; Clark and Williams, 1982).

The presence of Saos-2 cells in the culture medium modified the interface between the $\mathrm{Ti}$ surface and the proteins adsorbed from DMEM. Figure $3 \mathrm{c}$ and $\mathrm{d}$ show the Bode diagrams of the impedance modulus and phase angle versus frequency, respectively, of Ti-QCM surfaces cultured with Saos-2 osteoblasts for 1, 3, 5 and 7 days. The best fitting of the system was obtained considering two time constants (Fig. 3f). At high frequencies, the resistance of the electrolyte is higher than those values only in DMEM, without osteoblasts. At intermediate frequencies $\left(10^{2} \mathrm{~Hz}-10^{-2} \mathrm{~Hz}\right)$, the slope of approximately -0.85 could be attributed to one capacitor (CPE2) in parallel with a resistance (R2) that is associated with the interface that is created by the culture medium and the biomolecule 
(a)

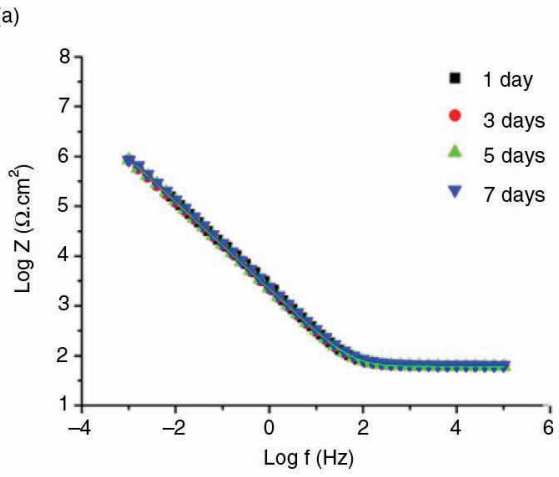

(b)

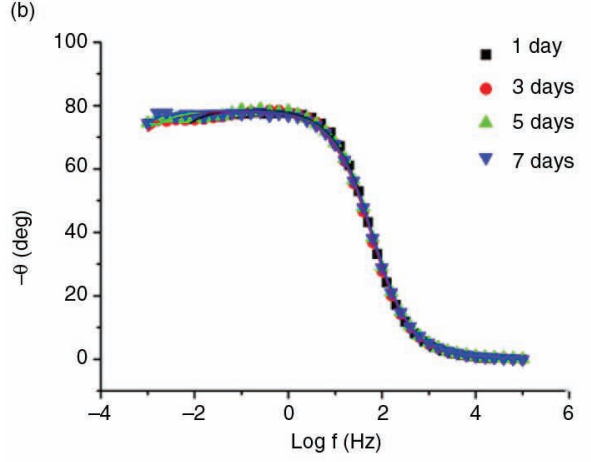

(c)
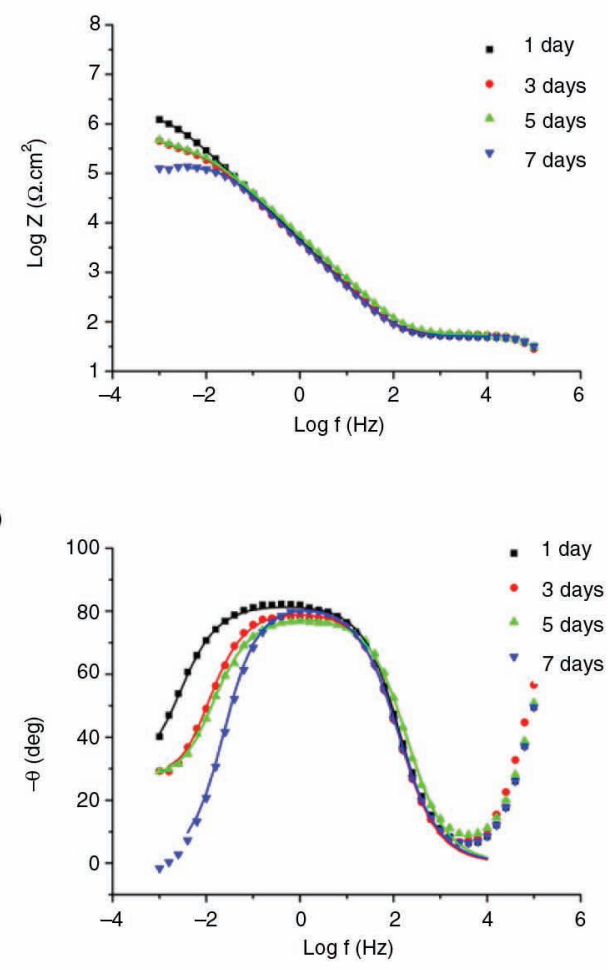

(e)
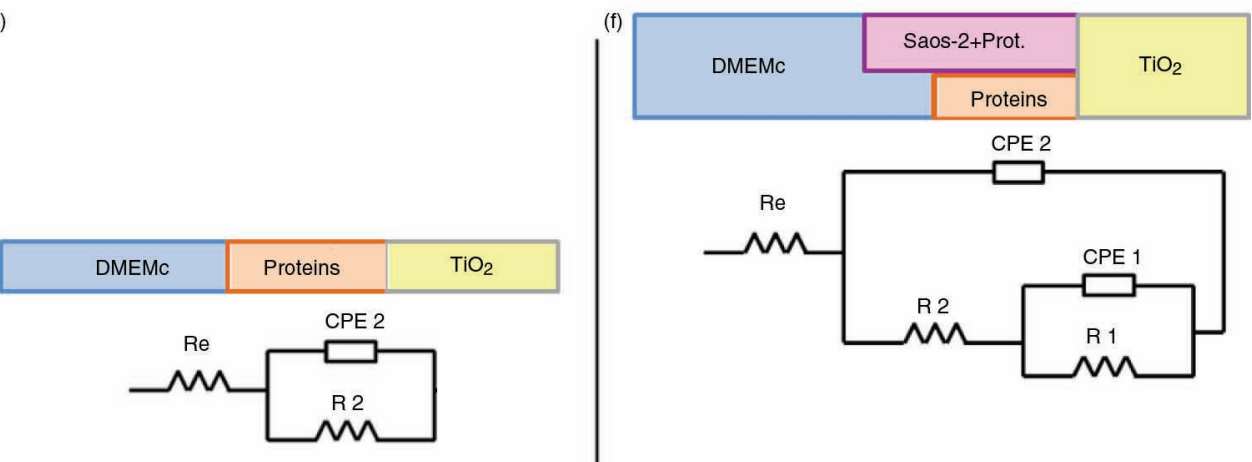

FIGURE 3. Impedance modulus and phase angle diagrams versus frequency of the Bode plots for: a) and b) Ti-QCM immersed in DMEM; c) and d) Ti-QCM cultured with Saos-2 osteoblasts in DMEM, respectively; e) equivalent circuit used for the DMEM/Ti-QCM interface; f) equivalent circuit used for the DMEM and osteoblasts/Ti-QCM interface.ø) $1^{\text {st }}$ day, •) $3^{\text {rd }}$ day, $\left.\mathbf{\Lambda}\right) 5^{\text {th }}$ day, $\left.\mathbf{v}\right) 7^{\text {th }}$ day, - Fitting data.

adsorption layer, containing cells and their extracellular matrix, formed on the Ti surface. At the lowest frequencies, the impedance values decrease until drawing a horizontal line the last day of testing in the impedance modulus of the Bode diagram that defines the resistance associated with the electrolyte and proteins/free of cell Ti surface interface (CPE1/R1).

According to the fit impedance results (Table 1), the pseudo capacitance (CPE2) of the biomolecule adsorption layer that integrates with Saos-2 cells increased with incubation time, suggesting that the cells rearranged the adsorbed proteins around them to adhere to titanium, possibly decreasing the amount of proteins that is adsorbed directly by titanium (Hiromoto et al., 2002). The approximate CPE2 values were $4 \times 10^{-5} \mathrm{~F} \cdot \mathrm{cm}^{-2}$, the same magnitude as the capacitance of the adsorption of albumin, fibrinogen, and thrombin to platinum (1 to $\left.10 \times 10^{-5}\right) \mathrm{F} \cdot \mathrm{cm}^{-2}$ (Lacour et al., 1991). Similarly, the $\mathrm{R} 2$ values decreased as the adsorbed protein concentration fell. The $\mathrm{Ti}$ oxide resistance $(\mathrm{R} 1)$ decreased and CPE1 values rose from the first day of incubation in Saos- 2 cells, becoming evident over time. This result indicates that the compounds that are generated by Saos- 2 cells, such as nitrous 
TABLE 1. Fitting EIS results for DMEM/Ti-QCM and Saos-2/Ti-QCM for 1, 3, 5 and 7 days of immersion

\begin{tabular}{|c|c|c|c|c|c|c|c|c|c|c|c|c|c|}
\hline & Time & Rs & $\mathbf{R} 2$ & & CPE2 & & & R1 & & CPE1 & & & \\
\hline & days & $\Omega$ & $\Omega \mathrm{cm}^{2}$ & $\%$ error & $\mu \mathrm{F} \cdot \mathrm{cm}^{-2}$ & $\%$ error & n2 & $\Omega \mathrm{cm}^{2}$ & $\%$ error & $\mu \mathrm{Ss}^{\mathrm{n}} \cdot \mathrm{cm}^{-2}$ & $\%$ error & n1 & $\chi^{2}$ \\
\hline \multirow[t]{4}{*}{ DMEM/Ti-QCM } & 1 & 132.7 & $3.310^{6}$ & 12.3 & 38.54 & 1.2 & 0.84 & & & & & & $1.1 \cdot 10^{-2}$ \\
\hline & 3 & 139.6 & $3.610^{6}$ & 17.9 & 48.18 & 1.2 & 0.83 & & & & & & $1.2 \cdot 10^{-2}$ \\
\hline & 5 & 138.2 & $2.910^{6}$ & 16.0 & 52.26 & 1.2 & 0.82 & & & & & & $1.2 \cdot 10^{-2}$ \\
\hline & 7 & 114.6 & $2.110^{6}$ & 12.3 & 53.28 & 1.2 & 0.83 & & & & & & $1.1 \cdot 10^{-2}$ \\
\hline \multirow[t]{4}{*}{ Saos-2/Ti-QCM } & 1 & 183.5 & $1.410^{6}$ & 10.5 & 40.89 & 2.5 & 0.91 & $2.910^{6}$ & 9.4 & 65.96 & 7.6 & 0.71 & $2.0 \cdot 10^{-3}$ \\
\hline & 3 & 194.3 & $3.310^{5}$ & 12.3 & 44.89 & 4.5 & 0.90 & $6.110^{5}$ & 11.5 & 136.64 & 4.0 & 0.71 & $1.7 \cdot 10^{-3}$ \\
\hline & 5 & 194.2 & $3.310^{5}$ & 13.0 & 36.61 & 4.6 & 0.87 & $6.410^{5}$ & 13.6 & 136.60 & 4.8 & 0.73 & $1.9 \cdot 10^{-3}$ \\
\hline & 7 & 180.9 & $1.210^{5}$ & 14.8 & 52.43 & 1.2 & 0.98 & $1.210^{4}$ & 21.4 & 203.21 & 6.7 & 0.78 & $2.4 \cdot 10^{-3}$ \\
\hline
\end{tabular}

oxide and superoxide, can dissolve the oxide film by chemical reaction, accelerating the dissolution of Ti-QCM surfaces (Jones, 1998).

Summarizing, the electrochemical interaction of Ti-QCM surface with osteoblast cells and the DMEM culture medium resulted in a decrease in the oxide film resistance over time, indicating there is a tendency to be more active, i.e., greater tendency toward corrosion. This trend can be explained by considering the association of two processes occurring simultaneously in the cell culture medium. On the one hand, considering only DMEM, the cell culture medium contains inorganic ions such as phosphate ions and calcium ions, and proteins as albumin competing for adsorption onto the metal surface. It is known that the $\mathrm{H}_{2} \mathrm{PO}_{4}^{-}$and $\mathrm{HPO}_{4}^{2-}$ can form a strong complexation bond with $\mathrm{Ti}$ by an exchange reaction with the basic hydroxyl groups (Healy and Ducheyne, 1992). The addition of Ca stabilizes the formation of a calcium phosphate film that can be progressively formed in a period of between 1 and 2 weeks (Lima et al., 2001). Also do not forget that certain proteins can form complexes that facilitate the dissolution of Ti. On the other hand, considering the presence of osteoblast cells, we must note that in the adhesion process to the metal surface, osteoblasts replace the adsorbed proteins from the cell medium by specific adhesion proteins (Hiromoto et al., 2002), generating extracellular matrix which acts as a cushion suitable for anchoring on the Ti surface. This very active and dynamic metabolism not only generates proteins but also highly reactive waste products, such as superoxide, nitrous oxide, protons, etc., all actively act on the Ti decreasing the corrosion resistance of the metallic material.

\section{CONCLUSIONS}

- Techniques, such as QCM and EIS, are valuable in monitoring the in situ adhesion and interaction of Ti surfaces and live cells.
- By QCM, the adhesion of Saos-2 cells to the Ti-QCM surface is a first-order reaction, with $\mathrm{k}=2.10^{-3} \mathrm{~min}^{-1}$.

- The effect of DMEM on Ti-QCM was observed for 7 days by EIS, demonstrating that the Ti resistance declines due to the presence of amino acids and proteins that are adsorbed.

- By EIS, the Ti resistance decreases by two orders of magnitude in the presence of Saos- 2 cells due to corrosive compounds that are generated by them.

\section{ACKNOWLEDGEMENTS}

The authors thank the financial support under projects MAT 2008-06719-C03-01, CTQ2008-05775/ BQU and by the Comunidad Autónoma de Madrid (CAM) through AVANSENS S2009/PPQ-1642.

\section{REFERENCES}

Alberts, B., Bray D., Lewis, J., Raff, M., Roberts, K., Watson, J.D. (1989). Molecular Biology of the Cell, $2^{\text {nd }}$ Ed. Garland, New York.

Alonso, C., García-Alonso, M.C., Escudero, M.L. (2008). Electrolytic cell used for electrochemical analysis of metallic implant and cell culture interface. Patent $\mathrm{n}^{\circ} 200801041$, España.

Burgos-Asperilla, L., García-Alonso, M.C., Escudero, M.L., Alonso, C. (2010). Study of the interaction of inorganic and organic compounds of cell culture medium with a Ti surface. Acta Biomater. 6 (2), 652-661. http://dx.doi. org/10.1016/j.actbio.2009.06.019.

Burgos-Asperilla, L., Gamero, M., Escudero, M.L., Alonso, C., García-Alonso, M.C. (2014). Interacción de compuestos inorgánicos y orgánicos de fluidos fisiológicos con superficies de Ti tratadas térmicamente. Rev. Metal. 50 (3), e022. http://dx.doi.org/10.3989/revmetalm.022.

Bruneel, N., Helsen, J.A. (1988). In vitro simulation of biocompatibility of Ti-Al-V. J. Biomed. Mater. Res. 22 (3), 203-214. http://dx.doi.org/10.1002/jbm.820220305.

Chen, Y.J., Feng, B., Zhu, Y.P., Weng, J., Wang, J.X., Lu, X. (2009). Fabrication of porous titanium implants with biomechanical compatibility. Mater. Lett. 63 (30), 2659-2661. http://dx.doi.org/10.1016/j.matlet.2009.09.029.

Clark, G.C., Williams, D.F. (1982). The effects of proteins on metallic corrosion. J. Biomed. Mater. Res. 16 (2), 125-134. http://dx.doi.org/10.1002/jbm.820160205. 
Echevarría, A., Arroyave, C. (2003). Evaluación electroquímica de algunas aleaciones para implantes dentales del tipo titanio y acero inoxidable. Rev. Metal. 39, 174-181. http:// dx.doi.org/10.3989/revmetalm.2003.v39.iExtra.1116.

Galli Marxer, C., Collaud Coen, M., Greber, T., Greber, U.F., Schlapbach, L. (2003). Cell spreading on quartz crystal microbalance elicits positive frequency shifts indicative of viscosity changes. Anal. Bioanal. Chem. 377 (3), 578-586.

García-Alonso, M.C. Saldaña, L., Alonso, C. Barranco, V. Muñoz-Morris, M.A., Escudero, M.L. (2009). In situ cell culture monitoring on a Ti-6Al-4V surface by electrochemical techniques. Acta Biomater. 5 (4), 1374-1384. http:// dx.doi.org/10.1016/j.actbio.2008.11.020.

Goreham, R.V., Mierczynska, A., Smith, L.E., Sedev, R., Vasilevet, K. (2013). Small surface nanotopography encourages fibroblast and osteoblast cell adhesion. RSC $A d v .3$ (26), 10309-10317. http://dx.doi.org/10.1039/C3RA23193C.

Healy, K.E., Ducheyne, P. (1992). Hydration and preferential molecular adsorption on titanium in vitro. Biomaterials 13 (8), 553-561. http://dx.doi.org/10.1016/0142-9612(92)90108-Z.

Hiromoto, S., Noda, K., Hanawa, T. (2002). Electrochemical properties of an interface between titanium and fibroblasts L929. Electrochim. Acta 48 (4), 387-396. http://dx.doi. org/10.1016/S0013-4686(02)00684-9.

Huang, H.H. (2004). In situ surface electrochemical characterizations of $\mathrm{Ti}$ and $\mathrm{Ti}-6 \mathrm{Al}-4 \mathrm{~V}$ alloy cultured with osteoblast-like cells. Biochem. Biophys. Res. Commun. 314 (3), 787-792. http://dx.doi.org/10.1016/j.bbrc.2003.12.173.

Jones, D.B. (1998). Cells and Metals in Metals as biomaterials, Ed. John Wiley and Sons, Chichester, England.

Kanazawa, K.K., Gordon, J.G. (1985). The oscillation frequency of a quartz resonator in contact with a liquid. Anal. Chim. Acta 175, 99-105. http://dx.doi.org/10.1016/ S0003-2670(00)82721-X

Khung, Y.L., Barritt, G., Voelcker, N.H. (2008). Using continuous porous silicon gradients to study the influence of surface topography on the behaviour of neuroblastoma cells. Exp. Cell Res. 314 (4), 789-800. http://dx.doi.org/10.1016/j. yexcr.2007.10.015.

Lacour, F., De Ficquelmont-Loizos, M.M., Caprani, A. (1991). Effect of the ionic strength of the supporting electrolyte on the kinetics of albumin adsorption at a glassy carbon rotating disk electrode. Electrochim. Acta 36 (11-12), 1811-1816. http://dx.doi.org/10.1016/0013-4686(91)85049-D

Lima, J., Sous, S.R., Ferreira, A., Barbosa, M.A. (2001). Interactions between calcium, phosphate and albumin on the surface of titanium. J. Biomed. Mater. Res. 55 (1), 45-53.
http://dx.doi.org/10.1002/1097-4636(200104)55:1<45::AIDJBM70>3.0.CO $2-2$.

Malik, M.A., Puleo, D.A., Bizios, R., Doremus, R.H. (1992). Osteoblasts on hydroxyapatite, alumina and bone surfaces in vitro: morphology during the first $2 \mathrm{~h}$ of attachment. Biomaterials 13 (2), 123-128. http://dx.doi.org/10.1016/ 0142-9612(92)90008-C.

Marx Kenneth, A., Zhou, T., Warren, M., Susan Braunhut, J. (2003). Quartz crystal microbalance study of endothelial cell number dependent differences in initial adhesion and steady-state behavior: evidence for cell-cell cooperativity in initial adhesion and spreading. Biotechnol. Progr. 19 (3), 987-999. http://dx.doi.org/10.1021/bp0201096.

Mendonça, G., Mendonça, D.B.S., Simões, L.G.P., Araújo, A.L., Leite, E.R., Duarte, W.R., Aragão, F.J.L., Cooper, L.F. (2009). The effects of implant surface nanoscale features on osteoblast-specific gene expression. Biomaterials 30 (25), 4053-4062. http://dx.doi.org/10.1016/j. biomaterials.2009.04.010.

Messer, D.K.R., Austin, G., Venugopalan, R. (2001). In vitro test system combining cell culture and corrosion techniques. Proc. Society for Biomaterials 27th Annual Meeting Transactions, Saint Paul, Minnesota, p. 221.

Modin, C., Stranne, A.L, Foss, M., Duch, M., Justesen, J., Chevallier, J. (2006). QCM-D studies of attachment and differential spreading of pre-osteoblastic cells on Ta and Cr surfaces. Biomaterials 27 (8), 1346-1354. http://dx.doi. org/10.1016/j.biomaterials.2005.09.022.

Mustafa, K., Pan, J., Wroblewski, J., Leygraf, C., Arvidson, K. (2002). Electrochemical impedance spectroscopy and X-ray photoelectron spectroscopy analysis of titanium surfaces cultured with osteoblast-like cells derived from human mandibular bone. J. Biomed. Mater. Res. 59 (4), 655-664. http://dx.doi.org/10.1002/jbm.1275.

Redepenning, J., Schlesinger, T.K., Mechalke, E.J., Puleo, D.A., Bizios, R. (1993). Osteoblast attachment monitored with a quartz crystal microbalance. Anal. Chem. 65 (23), 3378-3381. http://dx.doi.org/10.1021/ac00071a008.

Webster, T.J., Ergun, C., Doremus, R.H., Siegel, R.W., Bizios, R. (2000). Enhanced functions of osteoblasts on nanophase ceramics. Biomaterials 21 (17), 1803-1810. http://dx.doi. org/10.1016/S0142-9612(00)00075-2.

Yang, B., Uchida, M., Kim, H.M, Zhang, X., Kokub, T. (2004). Preparation of bioactive titanium metal via anodic oxidation treatment. Biomaterials 25 (6), 1003-1010. http:// dx.doi.org/10.1016/S0142-9612(03)00626-4. 